Faculdade de Ciências Econômicas UFRGS
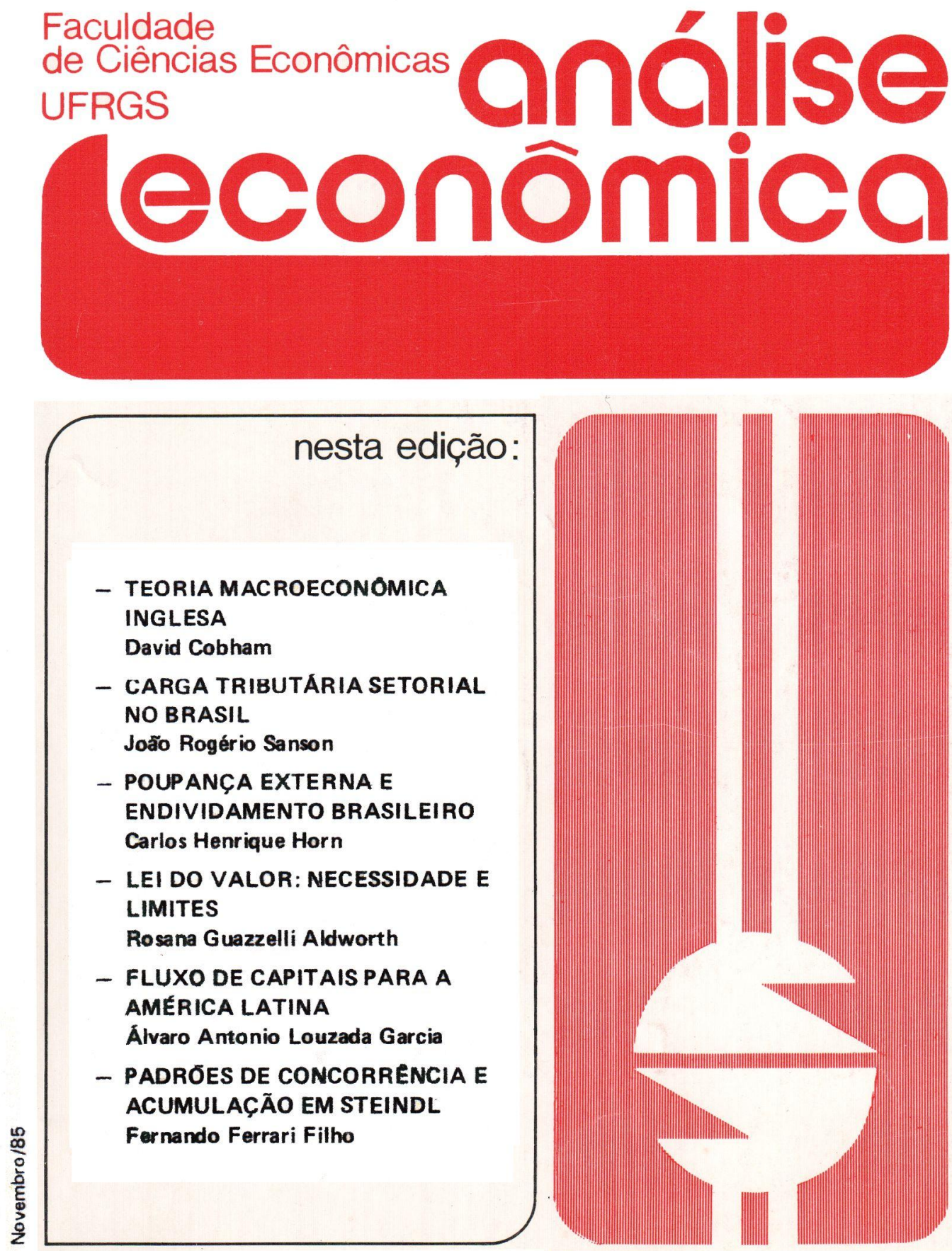

ano 3 
REITOR:Prof. Francisco Ferraz

DIRETOR DA FACULDADE DE CIÊNCIAS ECONÓMICAS:

Prof. Edgar lrio Simm

VICE-DIRETOR: Prof. Walter Meucci Nique

CHEFE DO DEPARTAMENTO DE CIENCIAS ECONOMICAS:

Prof. Renato Batista Masina

CONSELHO EDITORIAL: Prof. Pedro Cezar Dutra Fonsecs (Presidente)

Prof. Achyles Barcelos da Costa

Prof. Carlos Augusto Crusius

Prof. Claudio Francisco Accurso

Prof. Edgar Augusto Lanzer

Prof. Ernani Hickmann

Prof. Juvir Mattuella

Prof. João Rogério Sonson

Profa. Maria Imilda da Costa e Silva

Prof. Nali de Jesus de Souza

Prof. Nuno Renan L. de Figueiredo Pinto

Profa. Otilia Beatriz Kroeff Carrion

Prof. Paulo Alexandre Sphor

Prof. Roberto Camps Moraes

Profa。 Yeda Rorato Crusius

FUNDADOR: Prof. Antonio Carlos Santos Rosa

ANÁLISE ECONÔMICA publica dois números anuais nos meses de março e novembro. O preço da assinatura para 1986 é $\mathrm{Cr} \$ 20,000,00$, a ser pago através de cheque nominal para "Faculdade de Ciências Econômicas - UFRGS". Aceita-se permuta com revistas congêneres. Aceitam-se, também, livros para elaboração de resenhas ou recensões.

Toda a correspondência, material para publicação, assinaturas e permutas devem ser dirigidas a:

Prof. PEDRO CEZAR DUTRA FONSECA

Revista Análise Econômica

Avenida João Pessoa, $52-39$ andar

90.000 - Porto Alegre (RS) - Brasil 


\title{
O FLUXO DE CAPITAIS PARA A AMÉRICA LATINA: UMA BREVE RETROSPECTIVA HISTÓRICA
}

\author{
ALVARO ANTONIO LOUZADA GARCIA*
}

\section{INTRODUÇÃO}

O fluxo internacional de capitais vem merecendo um destaque especial na literatura econômica. Estudiosos de diversas correntes do pensamento econômicó têm debatido intensamente procurando esclarecer as causas do movimento de capitais bem como suas conseqüências no desenvolvimento das nações que emprestam e/ou captam recursos. Nesse contexto, a experiência da América Latina, tanto como absorvedora de capitais externos através de empréstimos e investimentos, como exportadora de recursos via pagamento de juros, amortização e lucros, é extremamente rica e ao mesmo tempo motivo de infindáveis polêmicas. Não porque o fluxo de capitais nessa regiäo ạssuma grandes proporções, visto que ele é relativamente pequeno quando comparado ao movimento de capitais entre os paises desenvolvidos. Mas porque, para os países latino-amcricanos, os recursos externos têm representado historicamente uma forma de inserção ao sistema capitalista mundial, com todas as conseqüências políticas, econômicas e sociais daí decorrentes. Desde as gueiras de independência nu começo do século XIX, passando pela Grande Depressão dos anos $\mathbf{3 0}$ até atingir a questão da dívida externa nos dias atuais, o movimento, de capitais na América Latina sempre foi

* Técnico da FEE; em fase de elaboração de Dissertação de Mestradio no Curso de Pósgraduaçăo em Economia do IEPE/UFRGS.

\begin{tabular}{|l|l|l|l|l|}
\hline ANALISE ECONOMICA & ANO 3 & No 5 & NOV/85 & p. 71.86 \\
\hline
\end{tabular}


motivo de acirrados debates, seja no ambate ideológico seja no âmbito estrito da formulação de política econômica.

O objetivo deste artigo é traçar um sumário histórico do fluxo de capitais para a América Latina e discutir algumas questões - sobre as causas e os efeitos desse fluxo - que são motivo de controvérsias entre os estudiosos do assunto. Para tanto, o trabatho foi dividido em três partes: a primeira se estende de aproximadamente 1820 até o início da Primeira Guerra Mundial; a segunda compreende o período entre as guerras, ou seja, de 1914 a 1945; na terceira parte a análise é centrada no período posterior à Segunda Guerra Mundial. Resta ainda acrescentar que algumas das questões controvertidas sobre o movimento de capitais não podern ser associadas a um único período de tempo, estando na verdade presentes em toda a história do fluxo de capitais. Assim, algumas questões que por exemplo são levantadas no estudo do 2 ? período poderiam ser apresentadas em qualquer um dos dois períodos aqui analisados.

\section{OS PRIMEIROS CEM ANOS: $1820 / 1914$}

As primeiras remessas de capitais para a América Latina datam da década de 20 do século passado ${ }^{1}$. Esses capitais eram oriundos sobretudo da Grã-Bretanha, então o país mais desenvolvido do mundo, e destinavam-se a cobrir os gastos das guerras de independência e as despesas públicas correntes dos países latino-americanos, que obtinham os fundos necessários emitindo bônus na praça de Londres. Nas três décadas seguintes - 30, 40 e 50 -, a maior parte do serviço da dívida nãc pôde ser pago dentro dos prazos estabelecidos, o que levou os países da região a constantes renegociações com os credores internacionais. Tal situaçao fez com que houvesse uma relativa estagnação no fluxo de empréstimos e investimentos estrangeiros, que só voltou a crescer a partir de 1860. Novamente é a Grã-Bretanha a maior fonte de recursos, agora secundada pela França e pela Alemanta. Nesses primeiros cem anos, no entanto, o auge do fluxo de capitais para a América Latina aconteceu no final do período, ou mais precisamente, da década de noventa até o início da 1a Guerra Mundial. Na América

1 - As informações sobre o movimento de capitais apresentadas neste trabalho, quando náo citada nominalmente a fonte, foram extraidas de: Naciones Unidas. Las Inversiones Extranjeras en America Latina. No. de venta: 1954. IL. G. 4. 
do Sul, a Argentina, o Uruguai, o Brasil e o Chile foram os países que mais se beneficiaram dos recursos externos. No começo do século, México e Cuba recebiam uma quantidade razoável de empréstimos oriundos dos EUA.

Dado esse quadro geral, pode-se discorrer sobre algumas questões relativas ao significado desses investimentos, que eram esmagadoramente do tipo portfólio (empréstimo). E claro que o movimento de capitais só foi possível porque existia um excedente nos países emprestadores e condições propícias ao investimento nos países tomadores. É óbvio também que os empréstimos foram realizados com um único objetivo: o lucro. Seria impossível pensar de outra forma na ańálisé de um sistema capitalista. Deve-se no entanto explicar as condições que tornaram viável a formação desse excedente, bem como a situação dos países latino-americanos que captaram esses recursos.

Desde a década de 20 do século passado, a Grã-Bretanha passou por quase 50 anos de prosperidade econômica. Em 1873, no entantc - tem início uma depressão que se prolonga por cerca de 20 anos, com os preços e os lucros caindo continuamente. Paralelamente há uma centralizaçāo da produção, com a indústria caminhando para a oligopolização.

Para J. A. Hobson ${ }^{2}$, um dos primeiros autores a estudar mais detalhadamente a exportação de capitais, esta se justifica porque na Grã-Bretanha não havia condições propícias ao investimento. A má distribuição de renda, diz Hobson, gerava uma poupança demasiadamente grande e concomitantemente uma demanda por produtos de consumo relativamente pequena. Dessa forma, os capital istas ingleses foram obriyados a aplicar seu excedente ao exterior. Já para Lenin ${ }^{3}$, o crescimento da exportação de capitais pelos países desenvolvidos é uma das características do imperialismo. A grande depressão de 1873-1896 ocasionou uma fusão do capital bancário com o capital industrial, dando origem ao "capital financeiro". Us grandes conglomerados que então se formavam investiram maciçamente no exterior, seja na busca de melhores taxas de lucro, o que era possível dado o reduzido preço da terra e dos salários nos países subdesenvolvidos, seja na luta pelo controle dos mercados e das fontes de matéria-prima.

2 - Hobson, J.A Imperialism. A Study. Allen \& Unwin, 1938. Apud Barratt Brown, M. A Economis Política do Imperialismo. Zahar Editores, 1978 pág. 158 e seguintes

3 - Lenin, V. I. O Imperialismo: Fase Superior do Capitalismo. Global Editora, 1982. 
Entre esses autores existe em comum, entre outras coisas, o fato de ambos associarem o movimento de capitais à situação de crise vivida pelas grandes potências, especialmente a Grã-Bretanha, o que fez com que os grandes conglomerados que iam se formando procurassem no exterior melhores oportunidades para seus investimentos. Assim, há uma relação causal entre a formação do capital monopolista e a exportação de capitais. Cronologicamente, está última somente se torna significativa quando da centralização do capital nas grandes poténcias, isto é, a partir do último quartel do século passado.

Num estudo mais recente, Knapp ${ }^{4}$ confronta dados sobre a exportação de capitais com informações estatísticas sobre a reinversão de juros e lucros. Analisando o período 1815-1914, ele demonstra que para os países desenvolvidos - Grã-Bretanha, França e Alemanha - os anos de acumulação externa mais rápida estão contidos no subperíodo 1855-1875. Entre 1875 e 1914, a maior parte do capital exportado correspondia, de fato, à reinversão de juros e lucros de investimentos realizados antes de 1870 , ou sejá, numa época de capitalismo competitivo. Dessa forma, contrariamente ao que pensavam Hobson e Lenin, Knapp afirma que não é correto estabelecer-se uma relação causal entre a gênese do capitalismo monopolista e o crescimento da exportação de capitais.

Por isso é preciso distinguir acumulação externa de exportação de capital.

Independente da estrutura de mercado que lhe deu origem, o certo é que existia um excedente nos países desenvoividos passível de ser transferido ao resto do mundo. Mas isso não bastava. Eram necessários outros fatores para tornar yiável o m!ovimento internacional de capitais. $O$ desenvolvimento das forças produtivas a nível mundial - crescimento da navegação transatlântica, produção de aço a baixos preços, métodos mais eficazes de refrigeração, novas técnicas de mineração - e o baixo preço da terra e dos salárics na América Latina foram os fatores decisivos para a realização dos investimentos. Nos países latino-americanos o capital estrangeiro foi aplicado basicamente nas lavouras de exportação, na mineração, nos serviços portuários e nas ferrovias.

4-Knapp, J. A. Capital Export and Growth. The Economic Journal, v. 48, n? 267. setembro de 1957. Apud Barrat Brown. M. op. cit. pág. 160 e seguintes e Cardoso. C.F. e Brignoli, H. P. História Económica da América Latina. Editora Graal, 1934, pág. 233 e seguintes. 
Normalmente a exportação de capitais estava associada à exportação de mercadorias. Se, por exemplo, um país necessitasse de um financiamento externo para a construção de uma ferrovia, o país emprestador condivionada a liberação do empréstimo à aquisição do material de construção e transporte no seu parque industrial. Assim, uma parte desses recursos retornava ao país emprestador como pagamento de trilhos, locomotivas, etc. Por outro lado, a parte restante do empréstimo era transformada em moeda local e diluída pelos segmentos da economia. Nesse caso, o aumento dos investimentos internos acabava gerando um crescimento da renda o que, dado o pouco desenvolvimento da indústria local nessa época, ocasionada um cumento das compras, no exterior, de bens de consumo. Dessa forma, o país emprestador não só aumentava seu crédito no exterior como também criava condições objetivas para o desenvolvimento de sua indústria de bens de capital e de bens de consumo.

Poderia parecer que os recursos externos pouca influência tiveram no desenvolvimento do setor interno dos países subdesenvolvidos, visto que esses capitais eram aplicados quase que exclusivamente nos setores de exportação e de infra-estrutura. Tal argumento no entanto é no mínimo discutível. As mesmas ferrovias que eram utilizadas para transportar o cáé do interior do Brasil e minerais do interior do Peru e do Chile para os respectivos portos de embarque serviam também para o traslado de outras mercadorias até as regiões produtoras, ou seja, o fluxo era nos do is sentidos. Exempios como estas mostram que, ainda que o objetivo com os investimentos estrangeiros fosse o de assegurar "o controle dos mercados e das fontes de matérias-primas", o capital externo, mesmo indiretamente, favoreceu o desenvolvimento das forças produtivas nos países latino-americanos. Resumindo, poderia se dizer que o crescimento dos setores de exportação e de infraestrutura, devido à expansão de renda que gerou e dada a conexão entre os diferentes setores da economia, acabou por beneficiar também setores ligados unicamente ao mercado nacional. Esse foi um dos fatores que viabilizou o rápido crescimento de setores do mercado interno quando do estancamento do fluxo de capitais para a América Latina.

\section{O PERIODO ENTRE AS GUERRAS: 1914-1945}

Envolvidos na Primeira Guerra Mundial, os países europeus praticamente cessaram seus empréstimos ao resto do mundo, e só 


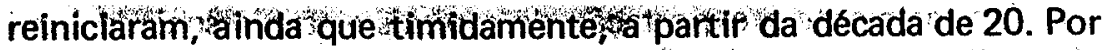
outro lado, os EUA, que ate o início da Guerra haviam limitado seus empréstimos ao México e à região do Caribe, expandiram o fluxo de capitais aos demais países da América Latina. Ainda que durante a Guerra esse movimento de capitais tenha sido pouco significativo, ele como que "abriu o caminho" para a expansão dos investimentos norte-americanos na região a partir de 1917.

O valor em dólares das inversões privadas dos EUA na América Latina cresceu $50 \%$ entre 1917 e 1919 e no final da década de 20 já era mais do que quatro vezes aquele de 1914. Entre 1925 e 1928, do total dos investimentos norte-americanos no exterior capitais de risco e de empréstimo - $24 \%$ foram absorvidos pelos países latino-americanos. Quando se consideram somente os investimentos diretos, o percentual aumenta: entre 1925 e 1929, 44\% do total dos capitais de risco transferidos dos EUA ao exterior destinaram se à América Latina. Esse elevado percentual pode ser explicado, em parte, pela alta rentabilidade dos bônus latino-americanos oferecidos no mercado dos EUA e que eram, em média, cerca de $40 \%$ acima da rentabilidade dos bônus norte-americanos. Ademais, no decênio de 1920 , cresceram consideravelmente os preços dos produtos exportados pela América Latina. Tendo aumentado seu volume cie divisas, o que em tese lhe permitia o pagamento da dívida sem maiores contratempos, essa região viu-se encorajada a obter maiores recursos no exterior. Assim é que a maioria dos países latino-americanos, mas em especial a Argentina, o Brasil, a Colômbia, o Chile e Cuba, aproveitou-se de uma conjuntura favorável para atrair do exterior capitais que, no entender de seus governantes, eram imprescindíveis ao desenvolvimento de suas economias nacionais.

A década de 30 , como todos sabem, fci catastrófica para a economia mundial, particularmente para a norte-americana. A Grande Depressão fez cessar o fluxo de capitais para a América Latina e, paralelamente, ocorreu uma redução nos preços e no volume das exportações dos produtos primários. Sem possibilidade de obter novos empréstimos e diante da brusca queda de suas exportações, não restou outra alternativa aos países latino-americanos senão a de suspender os pagamentos da dívida externa. Ao final de 1935 estavam em atraso $85 \%$ do valor total dos bônus emitidos em dólares pelos países da América Latina.

Da década de 30 até o começo dos anos 50 , ocorreu um macico repatriamento de capital, isto, é, particulares e governos da América Latina reduziram drasticamente sua dívida no exterior 
mediante a compra de bọnus em dólares, bônus esses quereram cotizados no mercado a valores bastante inferiores a seus valores nominais. A esse respeito diz a ONU: "Entre 1930 e 1945, o valor nominal dos bônus latino-americanos em dólares que haviam sido oferecidos publicamente e que estavam em poder de residentes nos EUA diminuiu em 1.100 milhões de dólares, ou seja, em cerca de $70 \%$. Depois da guerra, o repatriamento continuou num ritmo mais lento, porém os governos dos países devedores resgataram oficialmente uma parte ainda maior dos bônus. Dos aproximadamente 2.100 milhões de bônus em dólares que havia em poder de estrangeiros em 1930 somente restavam 767.000.000 no final de 1952. Nessa data, achava-se em poder de cidadãos dos EUA menos da metade dos nônus latino-americanos em dólares em circulação, e seu valor no mercado era inferior a 200.000 .000 de dólares. Os bônus latino-americanos em libras esterlinas experimentaram uma redução semelhante; no final de 1951 seu valor havia-se reduzido a cerca de 111.000 .000 de libras, em comparação com mais de 300.000 .000 de libras em 1939."5

O período entre as guerras é exemplar para a compreensão dos efeitos do movimento de capitais sobre o Balanço de Pagamentos. As Transações Correntes - balança comercial mais serviços - dos países subdesenvolvidos são tradicionalmente deficitárias, já que via de regra a balança comercial tende ao equilibrio e a conta de serviços é negativa. Dessa forma, é a entrada de recursos externos lançados na conta "movimento de capitais" que torna viável o "equilíbrio" do Balanço de Pagamentos. ${ }^{6}$ Isso permite que, em situações normais, os países devedores possam saldar seus compromissos externos sem a necessidade de reduzir o ritmo das âtividades internas, quer dizer, torna possível a manutençãc da capacidade para importar mesmo quando há déficit comercial e na conta de serviços, visto que esse déficit é "compensado" pela afluência de capitais externos.

A situação de "equilíbrio" descrita acima se torna extremamente vulnerável quando, por qualquer razão, cessa o fluxo de capitais. Foi o que aconteceu, por exemplo, durante as duas grandes guerras e na crise dos anos 30 . Mas nesses casos, e isso é muito

5 - Nacionés Unidas, op cit., pág 12. Traduzido do espanhol.

6 - Na verdade é um pseudo-equilibrio, na medida em que os recursos externos que entram para "zerar" o Balanço de Pagamentos serão pagos posteriormente através de amortizaçōes, juros e lucros. Essa é a causa principal do déficit crônico da conta de serviços dos paíse subdesenvolvidos. 
importante, a crise envolveu tanto os países credores quanto os paises devedores. Daí que a tentativa de resolvê-la incluiu a totalidade dos países, sendo possível até mesmo o repatriamento do capital que, como foi visto, deu-se mediante a compra de bônus em dólares a preços de mercado bastante abaixo de seus valores nominais. Será que isso seria possível se a crise fosse localizada num determinado país ou envolvesse apenas os países subdesenvolvidos? Certamente que não. Neste caso, o mais provável seria que os países credores simplesmente retirassem seus capitais do(s) país(es) devedor(es) e se recusassem a emprestar outros, levando a um aprofundamento da crise e às convulsões sociais daí decorrentes, como as que a história da América Latina tão tristemente registra.

Uma outra questão que merece ser destacada aqui é a que relaciona a gênese da industrialização dos países latino-americanos com o agravamento de suas contas externas. Durante as guerras mundiais e na depressão dos anos 30 , a interrupção da corrente de capitais e a queda dos preços e do volume dos produtos exportados havia ocasionado uma drástica redução na capacidade de importar. Daí a idéia de que, favorecida pela ausência de competição externa, a indústria latino-americana pôde desenvolver-se produzindo internamente artigos manufaturados que antes eram importados. Esse raciocínio parece correto na medida em que os dados comparavam o crescimento da produçao interna de bens de consumo nos períodos de agravamento das contas externas. Mas há um outro argumento, de certa forma complementar ao enunciado acima, que pode ser compreendido a partir da seguinte pergunta: como podia a indústria nacional atender à demanda crescente se para tanto necessitava aumentar sua capacidade de produção, ? que, em última instância, dependia da compra, no exterior, de bens de capital? Mesmo admitindo-se a hipótese de que, quando ocorreu a crise, havia uma capacidade ociosa ná indústria dos paises da América Latina, ainda assim seria preciso explicar quando foi formado esse parque industrial e que condições viabilizaram o seu crescimento. Por isso, parece mais correto associar o desenvolvimento industrial a dois momentos históricos: nos periodos de conjuntura favorável, o aumento da capacidade para importar, obtido entre outras maneiras pela entrada de capitais, permitiu a aquisição de máquinas e equipamentos que foram intensamente utilizados quando da necessidade de expansão dos produtos manufaturados, ou seja, nas crises. 


\section{O POS-GUERRA: $1945-1985$}

Desde a Primeira Guerra Mundial a Grã-Bretanha havia perdido o papel de centro financeiro mundial. Apesar do avanço norte-americano, principalmente durante os anos 20 do século atual, a Grande Depressão e a Segunda Guerra Mundial fizeram refluir o fluxo de capitais, de tal sorte que quando se analisa o período compreendido entre as guerras observa-se que nele não ocorreu uma hegemonia clara de nenhum país como centro do capitalismo financeiro internacional. Na tentativa de reorganizar o fluxo de capitais entre as nações, principalmente as do mundo capitalista, agora sob a liderança incontestável dos EUA, é que em 1944 um grupo de países criou duas instituições internacionais que deveriam financiar a reconstrução européia e o desenvolvimento dos demais países - Banco Mundial - e socorrer as nações que apresentassem desequilíbrio nos seus Balanços de Pagamentos - Fundo Monetário Internacional.

Os anso que se seguiram à criação desses organismos oficiais mostraram algumas diferenças importantes no movimento internacional de capitais. ${ }^{7}$ Em primeiro lugar, houve uma alteração na fonte dos empréstimos obtidos pela América Latina. Ao contrário do que ocorria antes da Segunda Guerra Mundial, quando os recursos eram obtidos basicamente junto ao setor privado, de 1945 até meados da década de 60 o Banco Mundial, o FMI e o BID - Banco Interamericano de Desenvolvimento, que começou a operar em 1961 - responderam por uma parcela considerável dos empréstimos ao Terceiro Mundo.

Além disso, houve nesse subperíodo um crescimento significativo dos investimentos diretos, onde expandiram-se consideravelmente as empresas denominadas multinacionais. Na América Latina essas inversčes concentraram-se em princípio nas indústrias petrolíferas, especialmente na Venezuela, e após 1950 expandiram-se a outros ramos da atividade econômica, como os

7 -- Ainda que ño seja objetivo deste trabalho analisar o fluxo de capita is a nivel mun dial, seria bom esclarecer que no pós-guerra ocorreu um deslocamento maciço de capitais norte-americanos para a Europa e o Japão, em detrimento da América Latina e outras regióes do mundo. Isso seria explicado por: 1 - a taxa de lucro ser altíssima na Europa, que já tinha grandes empresas e força de trabalho especializada; 2 - na época da guerra fria ser de interesse do governo norte-americano acelerar o crescimento econômico de seus novos aliados, pelo perigo que representava um crescimento da influência soviética na regiăo Vide a respeito Scaletsky, E. \& Oliveira, A. L.S.C. Contribuiçōes Metodológicas ao Estudo da Dependéncia na America Latina. Mimeo. 1983. 
da indústria de bens duráveis de consumo e da extração de miné. rios. Em 1950, os investimentos diretos norte-americanos haviam aumentado em cerca de 70\% quando comparados aos de 1943. Entre 1950 e 1953, saltaram de 4.700 milhões de dólares para 6.000 milhões de dólares, o que representa nesse curto período um acréscimo de $28 \%$. Há que se registrar, no entanto, que uma parte expressiva desses investimentos foi resultante da reinversão dos lucros aqui obtidos. Dados da ONU revelam que entre $1949 \mathrm{e}$ 1952 "cerca de $60 \%$ do aumento dos investimentos diretos norteamericanos em empresas estabelecidas na América Latina deveram-se aos lucros reinvestidos por filiais das respectiva empresas". ${ }^{8}$

A partir do final da década de 60 começa a diminuir novamente a participação relativa dos investimentos diretos no movimento de capitais. Utilizando-se de dados do BID. Frieden afirma que "enquanto na década de 1960 o investimento direto externo respondeu por aproximadamente $30 \%$ de todas as entradas de capital estrangeiro na América Latina, com empréstimos e obeigações bancárias respondendo por 10\%, na década de 1970 a participação das multinacionais caiu para $21 \%$, enquanto a participação dos financiadores privados internacionais aumentou para 59\%". 9 Há também uma outra alteração significativa quando se analisa a origem dos empréstimos por categoria de credores. Em 1960, 50,4\% da dívida pública externa da América Latina eram devidos a credores oficiais e $49,6 \%$ a credores privados. Em 1982, apenas $30,3 \%$ da dívida correspondiam a financiamentos obtidos junto a organismos oficiais, sendo os outros $69,7 \%$ oriundos de setor privado. ${ }^{10}$ entre todos os credores - públicos e privadcs - é notável o crescimento da participacão relativa dos bancos privados - bancos comerciais e instituições financeiras nrivadas - no total dos emprést imos concedidos à América Latina. Essa participação, qué em 1960 era de $16,4 \%$, atinge no final de 1932 cerca de $60 \%$ do total. $^{11}$

O aumento vertiginoso dos empréstimos bancários está normalmente associado ao surgimento do mercado de euromoedas e

8 - Naciones Unidas, op. cit., pág. 14. Traduzido do espanhol.

9 - Frieden, J. Finanças Internacionais e o Terceiro Mundo. In: Revista de Economia Política, vol. 5. n? 2, abril-junho/1985, pág. 102.

10 - BID - Banco Interamericano de Desenvolvimento. Progresso Sócio-Econômico na América Latina. Relatório de 1984, pág. 478.

11 - B1D. op cit., pág. 478 . 
aos dois "choques do Petróleo" - em 1973 e 1979.12 E por demais conhecida a relação que normalmente se estabelece entre os preços do pretôleo, o Euromercado e a dívida externa do Terceiro Mundo: o crescimento dos preços do petróleo, ao mesmo tempo que transferiu um grande volume de recursos para os países da OPEP - Organização dos Países Produtores de Petróleo -, ocasionou consideráveis desequilíbrio nos Balanços de Pagamentos das nações não produtoras de petróleo. Os países da OPEP investiram seus excedentes no Euromercado, que por sua vez retransferiu esses recursos, através de empréstimos, aos países do Terceiro Mundo, para que estes pudessem reequilibrar suas contas externas e continuar importanto, Resumidamente esse seria o mecanismo que explicaria a altíssima dívida do Terceiro Mundo. Mas na verdade não foi bem assim. A alta dos preços do petróleo teve um impacto mais modesto, tanto no Euromercado como na dívida dos países subdezenvolvidos.

Estudos mais recentes têm procurado, senão descaracterizar, pelo menos reduzir a importância da relação entre os lucros do petróleo e o crescimento do Euromercado. No já referido tra. balho de Frieden sobre "Finanças Internacionais e o Terceiro Mundo", ele mostra que os créditos de euromoedas de médio prazo para os países subdesenvolvidos não pertancentes à OPEP cresceram mais rapidarnente entre 1971 e 1973 do que entre 1973 e 1974. Esses créditos atingiram uma taxa de aumento anual de $87 \%$ entre 1972 e 1973 , contra $59 \%$ entre 1973 e $1974 .{ }^{13}$ Mais adiante, Frieden afirma o seguinte: “Entre 1974 e 1980, os países da OPEP depositaram 155 bilhões de dólares no sistema bancário mundial; pelo menos $4 / 5$ deste valor foi, provavelmente, para os Euromercados. No mesmo períodn, o novo empiéstimo bancário líquido internacional foi de 613 bilhões de dólares. Nos tres anos de 1976 a 1978, os países da OPEP depositaram uma média inferior a 10 bilhões de dólares por ano nos Euromercados, enquanto que a média dos empréstimos do Euromercado foi de 76 biIhōes por ano."14

12 - A denominaç⿸尸o "mercado de euromoedas" começou a ser utilizada no final dos anos 60 para caracterizar a grande importância quise passaram a ter no financiamento internacional as operações em moedas estrangeir as realizadas por bancos europeus. Na verdade é uma denominacão impropria, ou melhor, restritiva, na medida em que as opera çőes eram feiras por bancos sediados não só na Europa mas também em outras regiōes do mundo.

13 - Frieden, op. cit, pág. 99.

14 - Frieden, op cit., fógs, 89 e 100. 
A maior parte dos empréstimos obtidos pelos parses da América Latina foi canalizadà para o setor público. Os recursos foram predominantemente aplicados nas denominadas empresas estatais - usinas siderúrgicas, complexos petroliferos e petroquímicos, rede de telecomunicações, etc. - no sentido de desenvolver os setores básicos que ofertam matérias-primas para as indústrias de mercado interno e de exportação. A idéia básica dos responsáveis pela política econômica era de que a dinamização do parque industrial, além de desenvolver a indústria doméstica, daria ao país uma maior competitividade no exterior, com o conseqüente crescimento do volume das exportações. As divisas daí obtidas permitiriam o pagamento do serviço da dívida, mantendo-se assim a confiança dos credores, que estariam acessíveis a novos emprestimos.

Por outro lado, quando da formação do Euromercado - entre o final da décaúa de 60 e o começo dos anos 70 - os banqueiros internacionais também tirham perspectivas alentadoras. Em primeiro lugar, porque os países do Terceiro Mundo estavam dispostos a pagar taxas de juros acima da prime rate e da libor. ${ }^{15}$ Além disso, porque nessa época era alto o preço relativo das commodities, o que de certa forma servia como uma garantia de que no futuro os países teriam condições de realizar o pagamento das amortizações e dos juros. ${ }^{16}$

A situação relativamente tranqüila do início dos anos 70 começa a ficar tensa a partir do primeiro choque do petróleo. Os países desenvolvidos não produtures de petróleo, com o aumento dos preços desse produto, deveriam apresentar déficits nas suas balanças comerciais. Entretanto, como detinham um grande poder de barganha, dado o controle que exerciam no comércio mundial de mercadorias, conseguiram aumentar os preços inteıracionais doss produtos industrializados, relativamente ao dos produtos primários. Dessa forma, ao alterarem as relaçōes de troca, repassaram os déficits gerados pelo petróleo aos países do Terceiro Mundo. Estes acabaram duplamente penalizados: pelo aumentc dos preços do petróleo e pela queda dos preços dos produtos que exportavarm.

15 - Taxas de juros cobradas pelos bancos norte-americanos - prime - e ingleses libor - a seus clientes preferencia is.

16 - Na realidade, a confiança dos banqueiros náo era ilimitada. Talvez prevendo dificuldades na rolagem das obrigaçóes, como de fato ocorreu, prefeririam of erecer emprésti. mos a curto prazo. 
A medida que se aproximava o final da década, o pagamento do serviço da dívida foi ficando cada vez mais difícil. 0 segundo choque do petróleo teve um impacto bem mais limitado que o primeiro. A alta dos preços foi menor, muitos países haviam diminuído o consumo e em alguns já estava em andamento um processo de substituição de energia. Por outro lado, no entanto, a recessão nas economias industrializadas, que se acelerou no final do ano 70 , reduziu as trocas internacionais $e$, por conseguinte, o excedente comercial dos países subdesenvolvidos que era a principal fonte de recursos para o pagamento do serviço da dívida. Se os preços já não estavam bons, agora era o próprio volume das exportações que decrescia.

O golpe fatal nas contas externas dos países devedores veio com a alta dos juros, principalmente entre 1979 e 1981, embora até os dias atuais estes se mentenham em níveis relativamente elevados. Como os contratos de financiamento haviam sido realizados a juros variáveis, o volume da dívida ficou condicionado à evolução da taxa de juros internacional, ou, mais especificamente, à taxa de juros praticada no mercado norte-americano. Na tentativa de solucionar a crise do final dos anor 70, os EUA praticaram uma política monetária restritiva, o que elevou sobremaneira a taxa de juros e assim, indiretamente, a dívida do Terceiro Mundo, na medida em que a maioria dos contratos de financiamento haviam sido realizados em dólares.

Fica dessa forma demonstrado que o impacto dos preços do petróleo na dívida do Terceiro Mundo, ainda que significativo, foi menor do que aquele que costumeiramente é apresentado pelos governantes nara se justificarem perante se'ıs concidadãos. Aliás, se não fosse assim, como explicar que entre os grandes devedores encontram-se o México e a Venezuela, reconhecidamente do is dos maiores produtores mundiais de petróleo? Para o total da dívida latino-americana, que em meados de 1985 atingia 360 bithões de dólares, a do México colaborava com 95 bilhões e para a 2a maior do mundo, perdendo apenas para a dívida brasileira, estimada em cerca de 105 bilhões de dólares.

Pelo menos durante os últimos dez anos, os países da América Latina vêm encontrando dificuldades cada vez maiores para fazer frente ao serviço da dívida. Isso os obriga a permanentes renegociações com os credores internacionais, que normalmente são realizadas através do "testa-de-ferro" desses credores, o FMi. Em troca de recursos que lhes permitem "fechar" o Balanço de Pagamentos, as nações latino-americanas são muitas vezes obriga- 
das a aplicarem políticas recessivas, que deterioram as condições de vida de suas populações e são motivo de constantes convulsões sociais.

Na medida em que os recursos emprestados pelos bancos nada mais sấo que a poupança de cidadãos norte-americanos, europeus, japoneses, etc., os países devedores tornam-se na verdade "sócios" dos credores, porque o não-pagamento do serviço da dívida quebraria também os bancos. Essa "cumplicidade" dả aos paí. ses devedores, se unidos, um maior poder de barganha, que poderia se traduzir na exigência de melhores condições para o pagamento da dívida. Mas a ameaça da quebradeira geral, se assusta os países desenvolvidos, causa um temor muito maior nas elites latino-americanas. Por isso, o mais prováveç é que siga esse jogo de faz-deconta, com os credores ora exigindo mais ora exigindo menos - o que depende de situação econômica e política de cada país e os devedores prometendo coisas que sabem de antemão que não têm condições de cumprir. Até quando vai durar essa situação ninguém pode prever.

\section{CONCLUSOES}

O fluxo de capitais para a América Latina é tão antigo quanto a própria independência política dos países desta região. Nesses aproximadamente 160 anos de história, o movimento de capitais foi mais intenso durante a passagem do século $X I X$ para o século $X X$, nos anos 20 do século atual e após a Segunda Guerra Mundial. Inicialmente eram capitais de empréstimo fornecidos por credores da Grã-Bretanha e, num segundo plano, da França e da Alemanha. Durante à década de 20 , foram significativos os empréstimos e investimentos diretos, procedentes dos EUA. Nas primeiras décadas posteriores à Segunda Grande Guerra cresceram os dinanciamentos oriundos de instituições oficiais - Banco Mundial, BID e FMI -, e os investimentos diretos, principalmente norte-americanos. Nos últimos vinte anos, a grande maioria dos recursos obtidos pelos países latino-americanos foi conseguida junto a instituições privadas internacionais, através do chamado Euromercado.

Resumidamente, poderia se dizer que o capital externo teve um duplo efeito sobre os países da América Latina: por um lado permitiu que esses países pudessem de certa forma "queimar" etapas de seus processos de desenvolvimento; por outro, criou neles uina dependência cada vez mais acentuada em relação às economias industrializadas. 
Pelo menos uma parte dos recursos externos foi aplicada produtivamente nos países latino-americanos o que gerou um crescimento no emprego e na renda. Além disso, a captação de divisas aumentou a capacidade de importar e permitiu que esses países comprassem, no exterior, bens essenciais ao crescimento econômico. A própria gênese da industrialização dos países latino-americanos, que costumeiramente é associada à Primeira Guerra Mundial e à crise dos anos 30, só foi possível porque no começo do século eles haviam adquirido no exterior uma quantidade razoável de bens de capital. Da mesma forma, boa parte do desenvolvimento económico da América Latina nos anos 70 pode ser creditado à poupança externa.

Por outro lado, o pagamento do serviço da dívida e a remessa de lucros ao esterior vêm acarretando uma saída tão grande de divisas que os países latino-americanos são obrigados constantemente a recorrerem a novos empréstimos para fazer frente a seus compromissos externos. Mas o que importa ressaltar aqui é que essz-dependência do exterior para o "fechamento" do Ba. lanço de Pagamentos subordinou de tal maneira os países latino-americanos aos seus credores internacionais que nåo seria exagero afirmar que a política econômica desses países é hoje decidida nos gabinetes do FMI. Além disso, quanto maior a necessidade de divisas, maior a importância que assumem as exportações de mercadorias e de serviços. Assim, passou a existir uma outra forma de dependência: o atrelamento das economias latinoamericanas à conjuntura econômica dos países desenvolvidos. Qualquer crise que atinge esses últimos se reflete numa redução do comércio internacional de riıercadorias e serviços e, por conseguinte, cria uma dificuldade ainda maior para os paises latino-americanos saldarem seus débitos no exterior. Entre outras ocasiões, foi isso o que aconteceu nos anos 30 e no começo dos anos 80 .

Por fim, resta acrescentar que a afirmativa de que o capital externo ajudou os países latino-americanos a "queimar" etapas nos seus processo de desenvolvimento não significa dizer que com isso tenha havido uma redução na distância que os separa dos países desenvoividos. Muito pelo contrário, esse "fosso" é cada vez maior. $O$ que se está afirmando é que nada indica que o crescimento econômico seria maior se não houvesse afluência de capital externo. Algumas nações africanas e asiáticas estão aí para demonstrar isso. A internacionalizaçao do capital é ape- 
nas mais uma etapa do processo de desenvolvimento do capitalismo. Com todas as disparidades que ele é capaz de gerar.

\section{BIBLIOGRAFIA}

AMIN, Samir. O Desenvolvimento Desigual. Forense Universitária, Rio de Janeiro, 1976.

-. O Comércio Internacional e os Fluxos Internacionais de Capitais. In: Imperialismo e Comércio Internacional. Global, São Paulo, 1981.

ARRIAZU, Ricardo H. (Consultor). Movimentos Internacionales de Capitales. Cuadernos de la Cepal, Sant iago de Chile, 1979.

B1D - Banco Inter americano de Desenvolvimento. Progresso Sócio-Económico na Amé. rica Latina. Washington, Relatório de 1982.

-. Relatório de 1984.

BROWN, M. Barrat. A Economia Politica do Imperialismo. Zahar, Rio de Janeiro, 1978.

CALCAGNO, Alfred E. Informe sobre las Inversiones Directas Extranjeras en America Latina. Cuadernos de la Cepal, Santiago de Chile, 1980.

CARDOSO, Ciro F. \& BRIGNOLI, Héctor P. História Econômica da América Latina. Graal, Rio de Janeiro, 1984.

DAVIS, Tom E As Causas e Conseqüências da Divida Latino-Americana. In: Revista de Economia Política, Vol. 4, nọ 3, julho-setembro de 1984.

FRIEDEN, Jeff. Finanças Internacionais e o Terceiro Mundo. In: Revista de Economia Política, Vol. 5, abril-junho de 1985.

JALEE, Pierre. A Exploração do 39 Mundo. Zahar, Rio de Janeiro, 1968.

LENIN, V. I. O Imperialismo: Fase Superior do Capitalismo. Global, São Paulo, 1982.

MAGDOFF, Harry. Imperialismo: da era Colonial ao Presente. Zahar, Rio de Janeiro, 1979.

MUNHOZ, Dércio F. Financiamento Internacional: da Expanaşa ao Impasse Atual. In: Conjuntura Económica, Rio de Janeiro, dezembro de 1974.

NACIONES UNIDAS. Las inversiones extranjeras en America Latina. No de venta: 1954. II.G.5. Nueva York, 1955.

NIVEAU, Maurice. História dos Fatos Econĉ́nicos Contemporâneos. Difusão Européia, Sáo Paulo, 1969.

SCALETSKY, Eduardo \& OLIVEIRA, Ana L.S.C. Contribuição Metodológica ao Estudo da Dependéncia na América Latina. Mimeo, 1983. 